\title{
Characterization of isolates of Ralstonia solanacearum biovar 2, pathogenic to Eucalyptus "urograndis" hybrids
}

\author{
Eder Marques, Carlos H. Uesugi, Marisa A.S.V. Ferreira \& Denise V. de Rezende \\ Departamento de Fitopatologia, Instituto de Ciências Biológicas, Universidade de Brasília, 70910-900, Brasília, DF, Brazil
}

Author for correspondence: Carlos H. Uesugi, e-mail: uesugich@unb.br

\begin{abstract}
The objective of this study was to characterize isolates of biovar 2 of Ralstonia solanacearum pathogenic to eucalyptus "urograndis" hybrid by means of biochemical tests, as well as evaluation of host range and identification by PCR with primers for species, biovar and phylotype. Carbohydrate utilization assays revealed that the eucalyptus isolates belong to phenotype Tropical of biovar 2 (2T). From artificial inoculations it was possible to reproduce symptoms or recover the bacterium from: eucalyptus, potato, tomato, eggplant, datura, geranium, turnip, mustard, nasturtium, beetroot, sunflower, bean, French marigold, horseradish tree, and cashew. The PCR assays confirmed that the isolates belong to biovar 2, phylotype II of the bacterium. The confirmation of new biovar naturally infecting eucalyptus indicates that $R$. solanacearum easily adapts to new hosts.
\end{abstract}

Key words: bacterial wilt, biovar $2 \mathrm{~T}$, phylotype II.

\section{INTRODUCTION}

Commercial planting of eucalyptus (Eucalyptus spp.) in Brazil has intensified in recent years, and production has continued to match the country's demand. Of the total area of planted Brazilian forests, $63 \%$ is covered by eucalyptus (SBS, 2008). The success of this crop tree in Brazil is mostly attributed to the fast growth of interspecific eucalyptus hybrids, which can be easily propagated by clonal multiplication by rooting of cuttings and minicuttings. This system allows high yield and quality of wood for charcoal and cellulose production (Alfenas et al., 2009). However, the system of clonal propagation of eucalyptus is highly conducive to important and emergent diseases, such as bacterial wilt, caused by Ralstonia solanacearum (Smith) Yabuuchi et al. Bacterial multiplication and spread of disease by cuttings in nurseries is favored by folding of the roots, high temperature and humidity (Alfenas et al., 2006).

This bacterium is classified into races, according to its range of hosts (Buddenhagen \& Kelman 1964), and into biovars by means of carbohydrate utilization and growth on specific culture media (Hayward, 1964). Races and biovars are informal groupings at the infra-subspecific level not governed by the International Code of Nomenclature of Bacteria (Lapage et al., 1992). Fegan \& Prior (2005) proposed another classification at infra-subspecific levels phylotype is a monophyletic group based on ITS (internal transcribed

Part of the Doctoral Thesis of the first author. Universidade de Brasília. Brasília DF, Brazil. 2012. spacer) variations of DNA, and termed "sequevars", for that isolates identified by sequencing the endoglucanase genes. This classification has greater phylogenetic relevance in that it is stable over time.

Ralstonia solanacearum affects more than 200 species distributed among 50 botanical families (Hayward, 1994). Its range of hosts has been studied based on observation of symptoms in the field, then by isolation and fulfillment of Koch's Postulates (Álvarez et al., 2008).

Bacterial wilt of eucalyptus caused by biovar 1 has been responsible for losses of thousands of seedlings in nurseries in the Brazilian States of Bahia, Minas Gerais and Pará. Considering the lack of knowledge about genetic resistance and strategies for controlling the disease, it is essential to prevent the introduction of new strains of the bacterium into the nurseries (Alfenas et al., 2006). It is therefore important to characterize the pathogen at subspecific level, since these strains could differ in spread rate, virulence, geographic distribution, range of host, and other attributes (Hayward, 1994; Fegan \& Prior, 2005; Alfenas et al., 2006).

Race 3 biovar 2 (R3bv2), known as the "potato race", presents a limited range of natural hosts, being found in potato and occasionally in tomato (Solanum lycopersicum L.), eggplant (Solanum melongena L.) and sweet pepper (Capsicum annuum L.). It is prevalent in the South and Southeast of Brazil, but it also occurs in the cooler parts of generally hot regions, such as the Northeast of Brazil (Lopes, 2009). The range of hosts of R3bv2 continues to be somewhat confused, but more than 60 solanaceous and non-solanaceous plants, some wild and some domesticated, have been reported to be hosts, either by natural or artificial 
infection (Janse et al., 2004). There is little information about the interaction of $R$. solanacearum with the root system of wild plants exhibiting wilt symptoms or not (Hayward, 1994).

Reports of bacterial wilt in tree species are limited or poorly explained. Plants such as neem (Azadirachta indica A. Juss.), casuarina (Casuarina equisetifolia L.), cashew (Anacardium occidentale L.), custard apple (Annona squamosa L.), teak (Tectona grandis L.) and jambo (Eugenia javanica L.) have been described in a number of countries, showing symptoms triggered by various biovars of $R$. solanacearum (Supriadi et al., 2001).

The first report of bacterial wilt of eucalyptus in Brazil was in 1980, by Sudo et al. (1983). All reports are of Ralstonia solanacearum biovar 1 in America and biovar 3 in Asia, Oceania and Africa. Marques et al. (2009) described $R$. solanacearum R3bv2 in young plantations of Eucalyptus in Alexânia, State of Goiás, Brazil. The objective of this work was to characterize isolates of $R$. solanacearum biovar 2 pathogenic to eucalyptus in Brazil.

\section{MATERIAL AND METHODS}

\section{Origin of plant samples and bacterial isolates}

Samples of branches with bacterial wilt were collected from an infested area situated in the county of Alexânia (GO, Brazil), in February 2009. The area (latitude $16.00^{\prime} \mathrm{S}$ and longitude $48.26^{\prime} \mathrm{W}$, approximately) presented about 17 ha with eucalyptus. Originally covered in native cerrado vegetation, the area had recently been deforested. Relief is mountainous and the soil is an unweathered claysandy yellow latosol, with a large quantity of gravel. Plants of the hybrid Eucalyptus urophylla S. T. Blake x Eucalyptus grandis W. Hill ex Maiden ("urograndis") had originated from cuttings. At the time of collection, the plants showed a lack of uniformity in their growth and an average height of about $70 \mathrm{~cm}$ (phenological stage A), and most of the plants presented advanced wilt symptoms.

Analysis of these samples took place in the Bacteriology Laboratory of the Plant Pathology Department at the University of Brasília, Brasília (DF, Brazil).

\section{Isolation, cultivation and preservation of bacterial strains}

Segments of plant stalk were immersed in alcohol $70 \%$ for $30 \mathrm{~s}$ and sodium hypochlorite at $1 \%$ for $3 \mathrm{~min}$; washed twice with sterile distilled water; triturated in sterilized water drop and the exudates were diluted by streaking 523 medium of Kado \& Heskett (1970). After $48 \mathrm{~h}$ of incubation, individual colonies were transferred to Kelman's tetrazolium medium (Kelman, 1954), and then transferred to sterile distilled water in screw-top tubes.

\section{Biochemical characterization}

Pure colonies were submitted to the following biochemical tests: Gram, catalase, oxidase, O/F (oxidation and fermentation of glucose), fluorescence in King's medium B, biovar determination using the carbohydrates maltose, lactose, cellobiose, dulcitol, mannitol, and sorbitol) and determination of the phenotype of biovar 2 using trehalose and inositol (Hayward, 1994). Strains UnB 575 (R1bv1), UnB 1018 (R3bv2) and UnB 1173 (R1bv1) of $R$. solanacearum were used as positive controls (Table 1 ).

\section{Hypersensitivity reaction and pathogenicity test}

Hypersensitivity reaction (HR) was carried out on tobacco leaves (Nicotiana tabacum L. 'Havana 425'). Potato Achat cultivar plants and Eucalyptus "urograndis" hybrid seedlings were inoculated with the seven studied eucalyptus isolates and also with strain UnB 1173, R1bv1 (Table 1).

For the test of HR all the isolates were initially grown in Kelman's medium (Kelman, 1954) and the virulent colonies were selected after $48 \mathrm{~h}$ of incubation at $28^{\circ} \mathrm{C}$. A bacterial suspension of approximately $10 \times 10^{8} \mathrm{UFC} / \mathrm{mL}$ (McFarland Turbidity Standard No. 7) was infiltrated on the abaxial leaf surface of the test plants. Localized necrosis of the infiltrated area was observed 12-24 h after inoculation.

For the pathogenicity test in potato seedlings and eucalyptus mini-cuttings the virulent bacterial colony was rubbed on hypodermic syringe needles, which were then used to scratch the leaf axil. Fifteen plants of each species were used as replicates, with 10 of them inoculated with the bacteria and five not inoculated (controls). A soil test was also carried out for eucalyptus, where $50 \mathrm{~mL}$ of the bacterial suspension $\left(10^{9} \mathrm{UFC} / \mathrm{mL}\right)$ was distributed in the soil, soon after the roots had been wounded by using a pointed table knife. Non-inoculated mini-cuttings were used as control, also with wounds on the roots, and inoculated with only sterile distilled water. The plants were maintained in a greenhouse at $28^{\circ} \mathrm{C}$. Symptoms of infection by the bacterium were observed, including yellowing, chlorosis, purpling and watery lesions on the leaves, darkening of veins and tissues and wilt. Re-isolation of the pathogen took place in medium 523 (Kado \& Heskett, 1970) as previously described.

\section{PCR}

\section{Extraction of genomic DNA and general PCR conditions}

Purification of the total DNA of the bacterial genome was carried out using the Wizard ${ }^{\circledR}$ Genomic DNA Purifications Kit (Promega, Madison, WI). All the PCRs were carried out for a final volume of $25 \mu \mathrm{L}$, containing $1 \mathrm{X}$ Taq polymerase buffer (100 mM Tris-HCL pH 8.5, $500 \mathrm{mM}$ of $\mathrm{KCl}$ ); $30 \mathrm{ng}$ of target DNA and distilled water passed through a Milli-Q Water System (Milli-Q water, Millipore, Bedford, MS). The samples were submitted to amplification in a PT- $100^{\mathrm{TM}}$ thermocycler (MJ Research, Watertown, Mass) and electrophoresis was carried out at $85 \mathrm{~V}$ for one hour. After running the eletrophoresis, the gel was stained, destained and photographed in an LPix system from Loccus ${ }^{\circledR}$. 


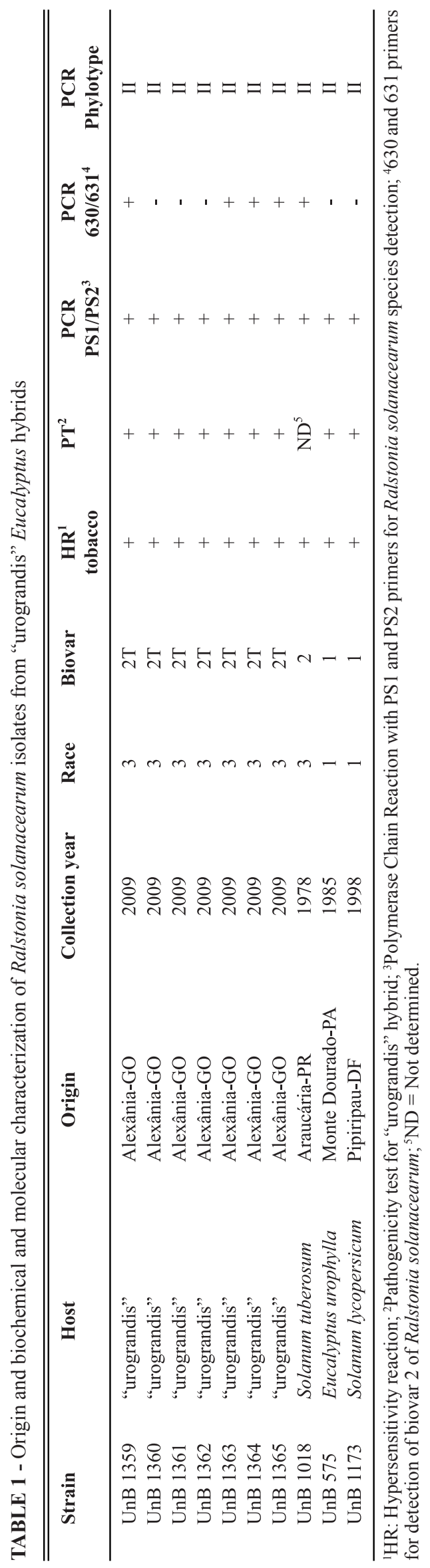


The marker used was 100 bp-Ladder ${ }^{\circledR}$ (Promega, Madison, WI). The differences for each primer are as follows.

\section{Identification with species-specific primers}

From purified DNA a fragment of rDNA from the 16S region was amplified by PCR, using primers PS-1 (5' AGT CGA ACG GCA GCG GGG G 3') and PS-2 (5' GGG GAT TTC ACA TCG GTC TTG CA 3'), which annealed with specific sequences for $R$. solanacearum (Pastrik \& Maiss, 2000). The reactions were carried out containing: $1.5 \mathrm{mM} \mathrm{MgCl}, 0.1 \mathrm{mM}$ of each of the deoxynucleotides (dATP, dTTP, dCTP, dGTP), $0.2 \mu \mathrm{M}$ of each of the oligonucleotides, $0.5 \mathrm{U}$ of Taq DNA polymerase enzyme. Initially the samples were heated to $95^{\circ} \mathrm{C}$ for $5 \mathrm{~min}$, then submitted to 35 cycles of $95^{\circ} \mathrm{C}$ for $30 \mathrm{~s}$ for denaturation, $30 \mathrm{~s}$ at $68^{\circ} \mathrm{C}$ for annealing of primers and $72^{\circ} \mathrm{C}$ for $45 \mathrm{~s}$ for extension, with final extension at $72^{\circ} \mathrm{C}$ for $5 \mathrm{~min}$. Positive controls were purified DNA from strains UnB 575, UnB 1018 and UnB 1173 of $R$. solanacearum (Table 1), and negative control was sterile water.

\section{Identification with primers to race 3 biovar 2} Primers 630 (5' ATA CAG AAT TCG ACC GGC AC 3') and 631 (5' ATA CAG AAT TCG ACC GGC AC 3') were used with genomic DNA (Fegan et al., 1998). The reaction was carried out containing: $0.25 \mathrm{mM}$ of each of the deoxynucleotides, $6 \mu \mathrm{M}$ of each of the oligonucleotides, The temperature of initial denaturation was $96^{\circ} \mathrm{C}$ for 10 min, followed by 30 cycles of: $94^{\circ} \mathrm{C}$ for $15 \mathrm{~s}, 60^{\circ} \mathrm{C}$ for 30 $\mathrm{s}$ and $72^{\circ} \mathrm{C}$ for $30 \mathrm{~s}$, with final extension at $72^{\circ} \mathrm{C}$ for 10 min. Positive control was strain UnB 1018 (R3bv2), and negative controls were purified DNA from strains of R1bv1 UnB 575, UnB 1173 (Table 1).

\section{Identification of the phylotype of the isolates of Ralstonia solanacearum}

The specific primers used for each phylotype were: I: Nmult:21:1F (5' CGT TGA TGA GGC GCG CAA TTT 3'); II: Nmult:21:2F (5' AAG TTA TGG ACG GTG GAA GTC 3'); III: Nmult:23:AF (5' ATT ACC AGA GCA ATC GAA AGA TT 3'), IV: Nmult:22:InF (5' ATT GCC AAG ACG AGA GAA GTA 3') and the conserved reverse primer: Nmult:22:RR ( ${ }^{\prime}$ 'TCG CTT GAC CCT ATA ACG AGT A 3') whose target region is the internal transcribed spacer (ITS) region between sequences $16 \mathrm{~S}$ and $23 \mathrm{~S}$ (Fegan \& Prior, 2005). The multiplex PCR contained: 1.25 $\mathrm{mM} \mathrm{MgCl}, 0.2 \mathrm{mM}$ of each dNTP, $0.4 \mu \mathrm{M}$ of each of the oligonucleotides, $2 \mathrm{U}$ of the Taq DNA polymerase enzyme. The initial denaturation temperature was $96^{\circ} \mathrm{C}$ for $5 \mathrm{~min}, 30$ cycles of $95^{\circ} \mathrm{C}$ for $15 \mathrm{~s}, 59^{\circ} \mathrm{C}$ for $30 \mathrm{~s}$ and $72^{\circ} \mathrm{C}$ for $30 \mathrm{~s}$, and a final extension at $72^{\circ} \mathrm{C}$ for $10 \mathrm{~min}$.

\section{Host test}

Twenty-five plant species (Table 2) were inoculated with three of seven isolates (UnB 1359, UnB 1360 and UnB 1364), so that they would represent the reports of the bacteriosis in some cultivated hosts, wild plants and species of trees. The test was carried out as described for the pathogenicity test in potato and eucalyptus.

\section{RESULTS}

\section{Biochemical and pathogenicity tests}

Soon after being collected and presenting symptoms of field wilt (Figure 1A), the eucalyptus plants showed an intense bacterial streaming (Figure 1B). From branches of several plants seven isolates were obtained, presenting colonies that were white, smooth, fluid, irregularly round and opaque. In Kelman's medium the virulent colonies presented a reddish center and white borders, while the avirulent ones were completely red (Figure 1C). Gram reaction was negative, there was no production of fluorescent pigment and they were catalase and oxidase positive. In the test of oxidation or fermentation of glucose, they were oxidative. The biovar tests indicated that they belong to the phenotype Tropical of biovar 2 (Table 1).

The hypersensitivity reaction of tobacco leaves (Figure 1D) occurred from $12 \mathrm{~h}$ after infiltration. Wilt in potato (Figure 1E) took place five days after inoculation, also showing intense bacterial streaming from the stalk (Figure 1F).

The appearance of symptoms in eucalyptus was later in the method of inoculation via soil than in the first pair of leaves. Even so, it was possible to observe symptoms of leaf fall, purpling of leaves and veins (Figure 1G), and inverted V-shaped blighting of leaves (Figure 1H) and darkening of the veins (Figure 1I). After nine months the bacterium could be re-isolated in culture medium. Strain UnB 1173 (Table 1) was also able to induce symptoms in eucalyptus plants. On the leaf inoculation method, when the leaves was wounded the symptoms appeared earlier, but these artificial inoculations did not show up bacterial streaming from the stalk in the eucalyptus plants.

\section{Identification of Ralstonia solanacearum isolates by PCR}

Amplification with the primers specific to the species $R$. solanacearum (Figure 2), based on the gene 16S rRNA, generated a fragment of approximately $553 \mathrm{bp}$ for all the tested isolates. Initially, in the PCRs carried out with primers for biovar 2 of the bacterium, the isolates UnB 1359, UnB 1361, UnB 1363, UnB 1364 and 1365 of R3bv2T of eucalyptus and isolate UnB 1018 R3bv2 of potato, a fragment of approximately $308 \mathrm{bp}$ was amplified under the conditions specified by Fegan \& Prior (2005). As well as the cited conditions, adjustments were made in the annealing temperature in an attempt to amplify the isolates that showed negative results for R3bv2T (UnB 1360, UnB 1361 and UnB 1362), testing at 55, 50 and $45^{\circ} \mathrm{C}$ and also with $1 \mathrm{U}$ of the enzyme Taq DNA 
TABLE 2 - Susceptibility of various species of plants to race 3 biovar 2 of Ralstonia solanacearum from "urograndis" eucalyptus hybrids

\begin{tabular}{|c|c|c|}
\hline Plant species tested & Family & HT* $^{*}$ \\
\hline Tomato (Solanum lycopersicum L.) & Solanaceae & + \\
\hline Eggplant (Solanum melongena L.) & Solanaceae & + \\
\hline Datura (Datura stramonium L.) & Solanaceae & + \\
\hline Geranium (Pelargonium $\times$ hortorum L.H. Bailey) & Geraniaceae & + \\
\hline Bean (Phaseolus vulgaris L.) & Leguminosae & + \\
\hline Lead tree (Leucaena glauca Benth.) & Leguminosae & - \\
\hline Beetroot (Beta vulgaris L.) & Chenopodiaceae & + \\
\hline Common purslane (Portulaca oleracea L.) & Portulacaceae & - \\
\hline Zucchini (Cucurbita pepo L.) & Cucurbitaceae & - \\
\hline Nasturtium (Trapaeolum majus L.) & Trapaeolaceae & + \\
\hline Turnip (Raphanus sativus L.) & Brassicaceae & + \\
\hline Mustard (Brassica juncea L.) & Brassicaceae & + \\
\hline Sweet potato (Ipomoea batatas L.) & Convolvulacae & - \\
\hline Sage (Salvia officinalis L.) & Lamiaceae & - \\
\hline French marigold (Tagetes patula L.) & Asteraceae & + \\
\hline Sunflower (Helianthus annuus L.) & Asteraceae & + \\
\hline Purple jambo (Eugenia javanica Lam.) & Myrtaceae & - \\
\hline Guava (Psidium guajava $\mathrm{L}$.) & Myrtaceae & - \\
\hline Clove (Syzygium aromaticum L.) & Myrtaceae & - \\
\hline Neem (Azadirachta indica A. Juss.) & Meliaceae & - \\
\hline Mulberry (Morus alba L.) & Moraceae & - \\
\hline Cashew (Anacadium ocidentale L.) & Anacardiaceae & + \\
\hline Custard apple (Annona squamosa L.) & Annonaceae & - \\
\hline Horseradish tree (Moringa oleifera Lam.) & Moringaceae & + \\
\hline Teak (Tectona grandis L.f.) & Verbenaceae & - \\
\hline
\end{tabular}

*HT: Host reaction after inoculation of the isolates of R3bv2T, by pricking the first pair of leaves with a needle, observation of the symptoms and re-isolation in culture medium. $(+)$ positive result and (-) negative result in the test.

polymerase. However, the fragment expected in these isolates was not observed, with only non-specific bands being visible (data not shown). In the PCRs to determine phylotype (Figura 3) fragments of $372 \mathrm{bp}$ were observed, which corresponded to phylotype II.

\section{Host test}

In the host test, 13 of the 25 tested species showed some disease symptom (Figure 4), allowing the bacterium to be re-isolated from infected branches: tomato, eggplant, datura, geranium, turnip, mustard, nasturtium, beetroot, sunflower, bean, French marigold, horseradish tree and cashew (Table 2). Some of these plants belonging to Solanaceae wilted rapidly (Figures 4A, B, C and D) between the third and fifth day after inoculation. These plants showed strong bacterial streaming from inoculated branches (Figure 4B), with the exception of datura. Geranium plants also showed yellowing, a typical symptom of wilt (Figure 4E), as well as signs of strong bacterial exudation (Figure 4F) and darkening of the veins (Figure 4G). By inoculating turnip plants it was also possible to observe bacterial exudation, permanent wilt, yellowing (Figure 4H) and vascular darkening (Figure 4J). Nasturtium also showed reduced growth, wilt (Figure 4L) and death 22 days after inoculation (Figure 4M). Beetroot presented purpling, wilt (Figure 4N) and death after strong tissue necrosis. Sunflower presented wilt, yellowing, excessive shoots and reduced growth (Figure 4O). In bean seedlings chlorosis could be seen in the leaves near the nerves and yellowing (Figure 4P). Seedlings of French marigold lost turgidity in the leaves by the second day after inoculation (Figure 4T).

Among the arboreal species, horseradish tree showed marked yellowing, wilt and reduced growth (Figure $4 \mathrm{Q}$ ), when compared to the negative control that was not inoculated with the bacterium, as well as necrosis of the inoculated branch (Figure 4R), 30 days after inoculation. Cashew plants showed dieback, excessive branching (Figure 4S) and excessive production of leaves near the inoculation site.

Seedlings of guava showed wilt after starting the test, dieback around where inoculations took place and leaf scorch (=inverted V-shaped necrosis). Common purslane (Portulaca oleracea) plants also wilted and died 30 days after inoculation. However, despite these symptoms it was not possible to recover the bacterium inoculated in guava or common purslane. Plants of custard apple, mulberry, purple jambo, clove, teak, 

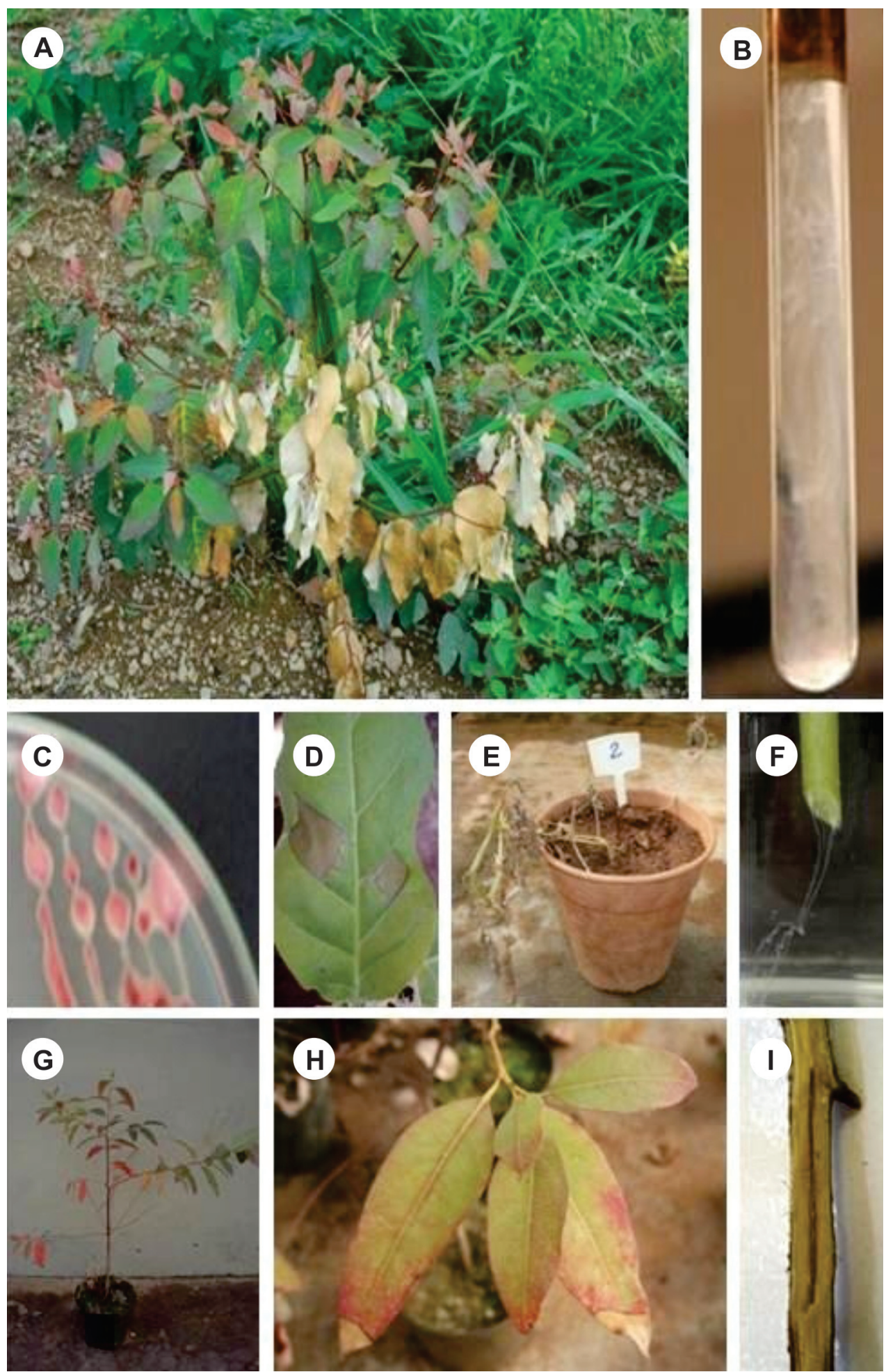

FIGURE 1 - A. Plant with symptoms of wilt in the field where the samples used in this work were collected; B. bacterial streaming observed soon after collecting samples; C. colonies on Kelman's medium with tetrazole; D. hypersensitivity reaction on tobacco leaves $12 \mathrm{~h}$ after inoculation; E. pathogenicity test in potato plants (cv. Achat) inoculated with the strain UnB 1359 showing severe wilt; F. bacterial streaming from freshly cut potato stem; G. eucalyptus plant nine months after starting the pathogenicity test, showing leaf fall and purpling of the leaves; H. symptom of inverted V-shaped blighting and purpling of the leaf stalk and I. longitudinal section of the eucalyptus branch, showing darkened veins. 


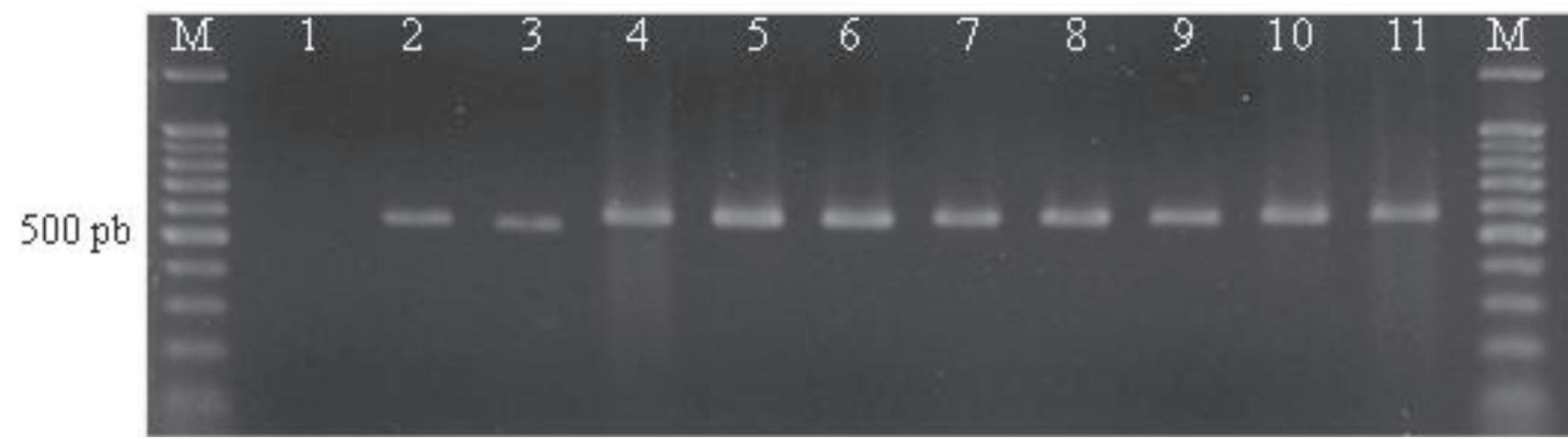

FIGURE 2 - Amplification of fragments of approximately 553 bp generated by primers PS-1/PS-2 that refer to the gene of region $16 \mathrm{~S}$ of the rRNA, from purified DNA from the isolates of Ralstonia solanacearum obtained from eucalyptus: M. 100 bp marker (Promega), 1. Negative control (sterile water), 2. UnB 575, 3. UnB 1018, 4. UnB 1173, 5. UnB 1359, 6. UnB 1360, 7. UnB 1361, 8. UnB 1362, 9. UnB 1363, 10. UnB 1364 and 11. UnB 1365.

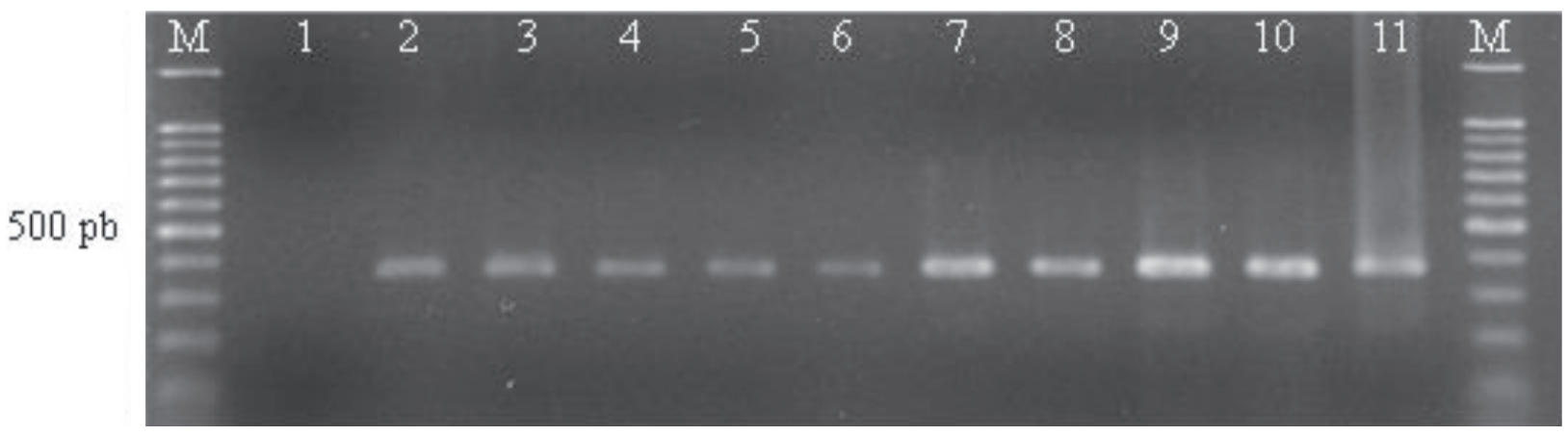

FIGURE 3 - Profiles of multiplex PCR amplification showing fragments of approximately 372 bp generated by primers specific for phylotype from purified DNA from the isolates of Ralstonia solanacearum obtained from eucalyptus: M. 100 bp marker (Promega), 1. Negative control (sterile water), 2. UnB 575, 3. UnB 1018, 4. UnB 1173, 5. UnB 1359, 6. UnB 1360, 7. UnB 1361, 8. UnB 1362, 9. UnB 1363, 10. UnB 1364 and 11. UnB 1365.

zucchini, sage and sweet potato seemed to be unaffected by these bacterial strains of $R$. solanacearum, because they did not exhibit symptoms or signs of infection and the attempts to re-isolate the inoculated bacterium were not successful.

\section{DISCUSSION}

The species Ralstonia solanacearum is cosmopolite, occurring naturally in soil around the world, including Australia and Indonesia (Santos et al., 2001). All reports of R. solanacearum in Eucalyptus spp. had previously shown biovar 1 in South America and biovar 3 in Asia, Oceania and Africa. However, natural infection on eucalyptus has been observed in the field, for the first time, via strains belonging to biovar 2, in the county of Alexânia (GO, Brazil) (Marques et al., 2009). The origin of the propagative material used on the farm is uncertain. The cuttings were probably obtained from nurseries in the State of Minas Gerais, but it is impossible to confirm whether the origin of the inoculum was contaminated cuttings from the source or if it was a natural occurrence of the pathogen in the soil of the region, because the area was recently deforested cerrado. According to Ferreira (2002), the damage caused by wilt in eucalyptus varies from 30 to $40 \%$ in recently deforested areas, and in the studied area there were no control measures taken, leading to the death of nearly $80 \%$ of the plants.

According to Silveira \& Higashi (2003) the evolution of diseases in the eucalyptus crop varies depending on the genetic material, age of the plants and climatic conditions. The tests of biovar determination made it possible to confirm the identity of the isolates from eucalyptus as $R$. solanacearum phenotype $\mathrm{T}$ of the biovar 2 , which is found in Brazil and Peru (Hayward, 1994). Biovar 2 occurs mainly in temperate areas in the Southern, Southeastern and Mid-western regions of Brazil (Reifschneider \& Takatsu, 1985). In Kenya this $R$. solanacarum biovar 2 causes wilt in tomato and potato at altitudes varying from 1200 to 2400 $\mathrm{m}$ (French, 1965). The average temperature and altitude 

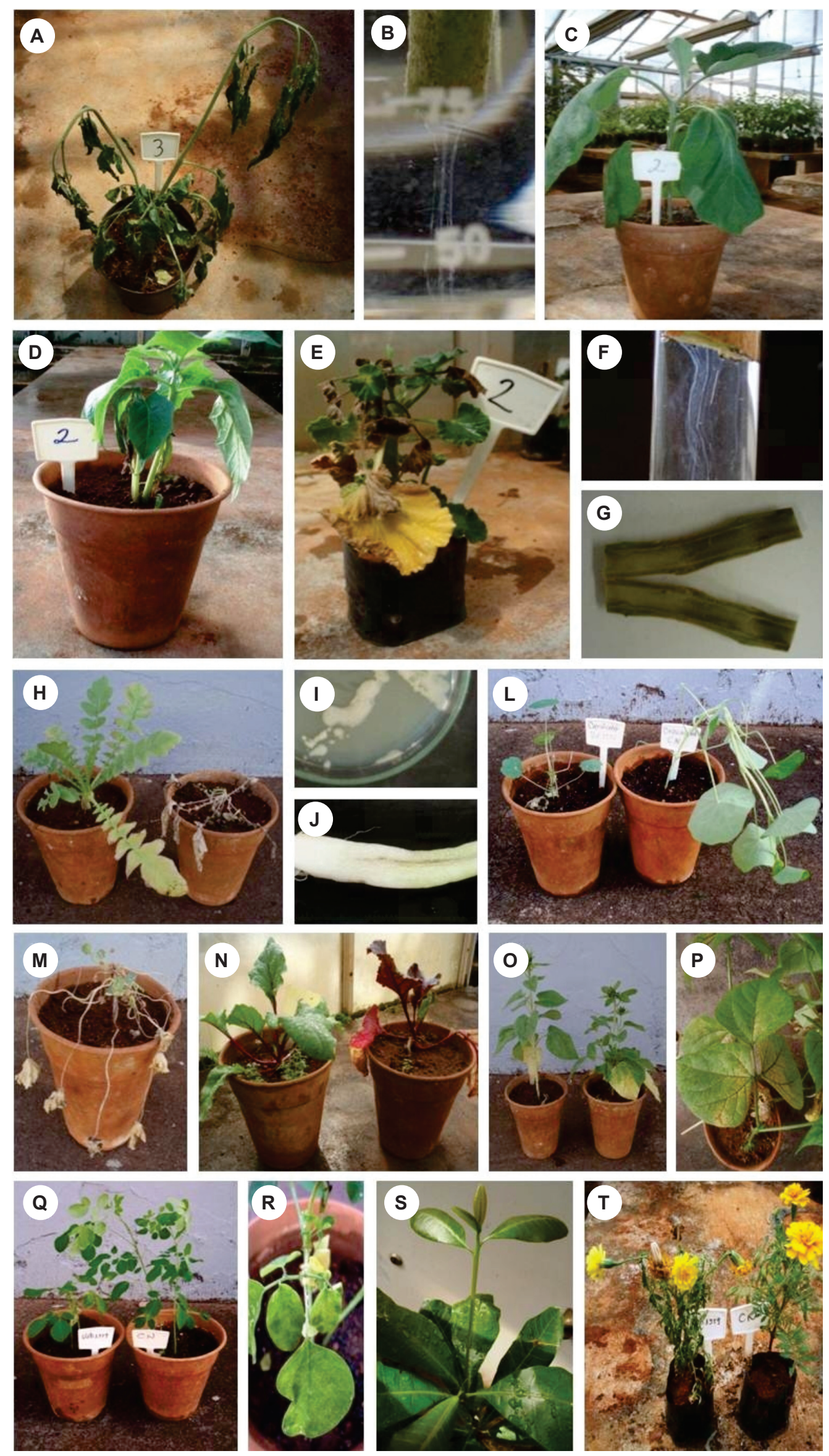

FIGURE 4 - Host test for strains of R3bv2 of eucalyptus: A. tomato seedling inoculated with strain UnB 1360, exhibiting wilt and excessive sprouting B. bacterial streaming in tomato; wilt in C. eggplant and D. datura; geranium exhibiting E. necrosis, yellowing and wilt of the leaves; $\mathbf{F}$. bacterial streaming and G. longitudinal section showing darkened veins; turnip plants H. on left, control plant, and on right, inoculated plant, wilting completely, I. bacterium re-isolated in culture medium and $\mathbf{J}$. longitudinal section of the root showing darkened veins; nasturtium L. on left, inoculated plant showing reduced growth, and on right, control plant and M. advanced wilt; N. beetroot: on left, noninoculated plant, and on right, inoculated plant showing purpling and wilt; O. sunflower plants: on left, control plant without bacterium, and on right, inoculated plant showing reduced growth, yellowing of leaves and excessive sprouting; P. bean plant with yellowing and necrosis of the nerves; horseradish tree $\mathbf{Q}$. on the left, inoculated plant showing reduced growth, and on right, control plant; R. detail of dieback and yellowed leaves; S. excessive growth of cashew branch near the inoculation site and $\mathbf{T}$. wilt in French marigold, on the left, inoculated plant, and on the right, control plant. 
are $21.3^{\circ} \mathrm{C}$ and $1100 \mathrm{~m}$ in Alexânia. Therefore, this region presents favorable characteristics for development of a strain originated from temperate climate regions.

In the tests of pathogenicity to eucalyptus, both by inoculation via pricking with a needle and by infection via injury to the roots of mini-cuttings in the soil, it was possible to recover the bacterium and observe typical wilt symptoms. However, there was no permanent wilt which generally occurs in small seedlings whose root system has been affected. Moreover, it is only under certain environmental conditions and with the predisposition of the host that severe symptoms appear, which is accomplished by an increase in bacterial colonization on xylem vessels (Alfenas et al., 2006). There is a difference between symptoms in mini-cuttings and in plants in the field. In the former, leaf turgidity is lost, but permanent wilt rarely occurs, unlike what is seen with young susceptible plants in the field. This may explain why older seedlings that have been inoculated in the root take nearly nine months to express symptoms in the greenhouse (Mafia, 2006).

Isolate UnB 1173 (biovar 1, of tomato) was also capable of inducing symptoms of wilt in eucalyptus plants in pathogenicity tests. It has already been demonstrated experimentally that strains belonging to certain other hosts were more virulent to $E$. grandis than were the strains belonging to these plants themselves (Dianese \& Dristig, 1993). This low specificity was also observed by Rodrigues (2010) in a microbiolization assay in vitro using eucalyptus seeds. The last author observed that from 22 studied strains, including biovars 1, 2 and 3 from various hosts, all isolates were capable of infecting eucalyptus plants and affecting their growth.

According to Janse et al. (2004), R3bv2 has more than 65 hosts including cultivated and wild solanaceous ones, and non-solanaceous. The tests for susceptibility of various plant species were positive for most plants tested, especially the solanaceous, confirming the criterion for race designation of Buddenhagen et al. (1964). Plants of turnip, geranium, sunflower, bean, beetroot and nasturtium were already considered to be hosts of this biovar, just confirming the reports in the literature (Janse et al., 2004). As well as these, it was observed that strains of race 3 biovar $2 \mathrm{~T}$ of eucalyptus also affected the arboreal species, horseradish tree and cashew, and these species are also described as susceptible to other $R$. solanacearum biovars in India and Indonesia (Supriadi et al., 2001).

To make a more complete identification of $R$. solanacearum strains it is currently necessary to add to biochemical tests a DNA based method (Champoiseau \& Jones, 2009). Thus, the primers used in the PCRs corroborated the biochemical tests. These primers described by Fegan et al. (1998) were designed from prophage sequences or were those that remained in many or all of the R3bv2 strains (Gabriel et al., 2006). According to Guidot et al. (2009), in the long term these genes might not be completely reliable for identification purposes, because they have the capacity to move from one bacterium to another. Observation of primers for phylotype was as expected, since a number of studies have shown that isolates of potato of biovars $2 \mathrm{~T}$ and 1 belong to phylotype II. Ji et al. (2007) studied the genetic diversity of $R$. solanacearum and revealed that R3bv2 isolates of potato from Brazil, the Netherlands, Reunion Islands, Australia and Peru, and of geranium from Kenya, belonged to phylotype II. Later, the same was observed by Castillo \& Greenberg (2007) in a study of isolates from various parts of the world.

This paper describes for the first time bacterial wilt of eucalyptus caused by race 3 biovar $2 \mathrm{~T}$ of $R$. solanacearum in natural field conditions. The findings confirm the high adaptability, versatility and wide range of hosts of $R$. solanacearum and alert us to the possibility of new infections in the field and in nurseries of eucalyptus and other plants, such as Moringa oleifera (Moringa) and Anacardium occidentale (cashew), species susceptible to bacterial wilt triggered by other biovars of $R$. solanacearum in other countries.

\section{ACKNOWLEDGEMENTS}

The authors acknowledge the financial support and scholarship granted to Eder Marques by the Conselho Nacional de Desenvolvimento Científico e Tecnológico CNPq.

\section{REFERENCES}

Alfenas AC, Zauza EAV, Mafia RG, Assis TF de (2009) Clonagem e doenças do eucalipto. $2^{\text {a }}$ Ed. Viçosa MG. Editora UFV.

Alfenas AC, Mafia RG, Sartório RC, Binoti DHB, Silva RR, Lau D, Vanetti CA (2006) Ralstonia solanacearum em viveiros clonais de eucalipto no Brasil. Fitopatologia Brasileira 31:357-366.

Álvarez B, Vasse J, Le-Courtois V, Trigalet-Démery D, López MM, Trigalet A (2008) Comparative behavior of Ralstonia solanacearum biovar 2 in diverse plant species. Phytopathology 98:59-68.

Buddenhagen I, Kelman A (1964) Biological and physiological aspects of bacterial wilt caused by Pseudomonas solanacearum. Annual Review of Phytopathology 2:203-230.

Castillo JA, Greenberg JT (2007) Evolutionary dynamics of Ralstonia solanacearum. Applied and Environmental Microbiolgy 73:1225-1238.

Champoiseau PG, Jones JB (2009) Ralstonia solanacearum race 3 biovar 2 causes tropical losses and temperate anxieties. Plant Health Progress. Available at: http://www.apsnet.org/publications/ apsnetfeatures/pages/ralstonia.aspx

Dianese JC, Dristig MCG (1993) Screening Eucalyptus selections for resistance to bacterial wilt caused by Pseudomonas solanacearum. In: Hartman GL, Hayward AC (Eds.) International Bacterial Wilt Symposium. Proceedings... Kaoshiung Taiwan. pp. 206-210.

Fegan M, Prior P (2005) How complex is the "Ralstonia solanacearum species complex"? In: Allen P, Prior P, Hayward 
AC (Eds.) Bacterial wilt disease and the Ralstonia solanacearum species complex. St Paul MN. APS Press. pp. 449-461.

Fegan M, Taghavi M, Sly LI, Hayward AC (1998) Phylogeny, diversity and molecular diagnostics of Ralstonia solanacearum. In: Prior P, Allen C, Elphinstone JG (Eds.) Bacterial wilt disease - molecular and ecological aspects. Berlin Germany. SpringerVerlag. pp. 19-33.

French ER (1965) Interaction between strains of Ralstonia solanacearum, its hosts and the environment. International Workshop PCARRD. Proceedings... Los Banos The Philippines. pp. 94-104.

Gabriel DW, Allen C, Schell M, Denny TP, Greenberg JT, Duan YP, Flores-Cruz Z, Huang Q, Clifford JM, Presting G, González ET, Reddy J, Elphinstone J, Swanson J, Yao J, Mulholland V, Liu L, Farmerie W, Patnaikuni M, Balogh B, Norman D, Alvarez A, Castillo JA, Jones J, Saddler G, Walunas T, Zhukov A, Mikhailova $\mathrm{N}$ (2006) Identification of open reading frames uniqueto a select agent: Ralstonia solanacearum race 3 biovar 2. Molecular Plant Microbe Interactions 19:69-79.

Guidot A, Elbaz M, Carrère S, Siri MI, Pianzzola MJ, Prior P, Boucher C (2009) Specific genes from the potato brown rot strains of Ralstonia solanacearum and their potential use for strain detection. Phytopathology 99:1105-1112.

Hayward AC (1994) The hosts of Pseudomonas solanacearum. In: Hayward AC, Hartman GL (Eds.) Bacterial wilt: The disease and its causative agent, Pseudomonas solanacearum. Willingford UK. CAB International. pp. 25-34.

Hayward AC (1964) Characteristics of Pseudomonas solanacearum. Journal of Applied Bacteriology 27:265-277.

Janse JD, van den Beld HE, Elphistone J, Simpkins S, Tjou-Tam NNA, Vaerenbergh J (2004) Introduction to Europe of Ralstonia solanacearum biovar 2, race 3 in Pelargonium zonale cuttins. Journal of Plant Pathology 86:147-155.

Ji P, Allen C, Sanchez-Perez A, Yao J, Elphinstone JG, Jones JB, Momol MT (2007) New diversity of Ralstonia solanacearum strains associated with vegetable and ornamental crops in Florida. Plant Disease 91:195-203.

Kado CI, Heskett MG (1970) Selective media for isolation of Agrobacterium, Corynebacterium, Erwinia, Pseudomonas and Xanthomonas. Phytopathology 60:969-976.

Kelman A(1954) The relationship of pathogenicity in Pseudomonas solanacearum to colony appearance on a tetrazolium medium. Phytopathology 44:693.
Lapage SP, Sneath PHA, Lessel EF, Skerman VBD, Seelinger HPR, Clark WA (1992) International Code of Nomenclature of Bacteria. Washington DC. American Society of Microbiology.

Lopes CA (2009) Murcha bacteriana ou murchadeira - uma inimiga do tomateiro em climas quentes. Brasília DF. Comunicado Técnico Embrapa 67. Available at: http://bbeletronica.cnph. embrapa.br/2009/cot/cot_67.pdf

Mafia RG (2006) Sintomatologia, etiologia e controle da murcha bacteriana do eucalipto. Tese de Doutorado, Universidade Federal de Viçosa. Viçosa MG.

Marques E, Rezende DV, Uesugi CH (2009) Primeiro relato da biovar 2 de Ralstonia solanacearum em eucalipto no Brasil. Tropical Plant Pathology (Supl.) 34:12.

Pastrik KH, Maiss E (2000) Detection of Ralstonia solanacearum in potato tubers by polymerase chain reaction. Journal of Phytopathology 48:619-626.

Reifschneider FJB, Takatsu A (1985) Pseudomonas solanacearum no Brasil - aspectos macroepidemiológicos. Fitopatologia Brasileira (Supl.) 10:213.

Rodrigues LMR (2010) Avaliação da agressividade e caracterização genética de linhagens de Ralstonia solanacearum isoladas de diferentes plantas hospedeiras. Tese de Mestrado, Universidade Estadual Paulista, Faculdade de Ciências Agronômicas. Botucatu SP.

Santos AF, Auer CG, Grigoletti Jr. A (2001) Doenças do eucalipto no sul do Brasil: identificação e controle. Colombo PR. (Circular Técnica Embrapa, 45). Available at: http://www.cnpf.embrapa.br/ publica/circtec/edicoes/circ-tec45.pdf

SBS (2008) Sociedade Brasileira de Silvicultura - Fatos e números do Brasil florestal. Available at: http://www.sbs.org.br/ FatoseNumerosdoBrasilFlorestal.pdf

Silveira RLV da A, Higashi EN (2003) Aspectos nutricionais envolvidos na ocorrência de doenças com ênfase para o eucalipto. Piracicaba SP. (Circular Técnica IPEF, 200). Available at: http:// www.ipef.br/publicacoes/ctecnica/nr200.pdf

Sudo S, Oliveira GHN, Pereira AC (1983) Eucalipto (Eucalyptus sp.) e bracatinga (Mimosa scabrella Penth), novos hospedeiros de Pseudomonas solanacearum E.F. Smith. Fitopatologia Brasileira (Supl.) 8:631.

Supriadi D, Karden M, Sitepu D (2001) Bacterial wilt disease of woody trees caused by Pseudomonas solanacearum: a review. Jurnal Litbang Pertanian 20:106-112. 